\title{
EFFEK ASAM LEMAK OMEGA 3, OMEGA 6 DAN KOLESTEROL SINTETIS TERHADAP REPRODUKSI PUYUH JANTAN (COTURNIX COTURNIX JAPONICA) DALAM MENINGKATKAN PENDAPATAN PETERNAK
}

\author{
Abyadul Fitriyah $^{1 *}$, Isyaturriyadhah ${ }^{2}$ \\ ${ }^{1}$ Program Studi Peternakan, Fakultas Peternakan, Universitas Nahdlatul Wathan Mataram, Mataram, Indonesia \\ ${ }^{2}$ Program Studi Agribisnis, Fakultas Pertanian, Universitas Muara Bungo, Jambi, Indonesia \\ Email: abyadulfitriyah@gmail.com
}

Diterima: 11 Februari 2021. Disetujui: 24 Maret 2021. Dipublikasikan: 26 April 2021

\begin{abstract}
ABSTRAK
Penelitian bertujuan mengetahui pengaruh penggunaan asam lemak omega 3, omega 6 dan kolesterol sintetis terhadap kadar hormon testosteron, Frekuensi suara dan organ reproduksi puyuh jantan (coturnix coturnix japonica). Penelitian menggunakan 175 ekor burung puyuh jantan dibagi menjadi tujuh kelompok perlakuan yaitu R0 (kontrol), R1 (0,163 mg eicosapentaenoic acid), R2 (0,326 mg eicosapentaenoic acid), R3 (0,163 mg 5,8,11,14 eicosatetraenoic acid), R4 (0,326 mg 5,8,11,14 eicosatetraenoic acid), R5 (20 mg cholesterol NF), R6 (40 mg cholesterol NF). Perlakuan asam lemak dan kolesterol diberikan per oral selama lima (5) hari berturut-turut untuk masing-masing kelompok perlakuan. Data dianalisa dengan analisis variansi menggunakan RAL, dilanjutkan dengan uji kontras ortogonal dan uji morpometri. Hasil penelitian : Penggunaan asam lemak omega 3 dan omega 6 dua kali dosis $(0,326 \mathrm{mg})$ menunjukkan respon yang terbaik, yaitu peningkatan pada berat testis, panjang testis, lingkar testis dan volume testis. Kadar hormon testosteron tertinggi ditunjukkan oleh perlakuan R2. Secara keseluruhan dapat disimpulkan bahwa penggunaan $0,326 \mathrm{mg}$ asam lemak omega 3 dan omega 6 berpengaruh terhadap peningkatan organ reproduksi, kualitas suara dan kadar hormon testosteron plasma darah burung puyuh jantan.
\end{abstract}

Kata Kunci: Omega 3, Omega 6, Kolesterol, Reproduksi jantan

\begin{abstract}
This research aims to know the effects of using Omega 3, Omega 6 Fatty Acid and Cholesterol synthetic on Hormone Testosterone Level, voice frequency, and male quails reproduction organ. The research used 175 male quails which were divided in to 7 treatment groups; R0 (control), R1 (0,163 mg eicosapentaenoic acid), R2 (0,326 $\mathrm{mg}$ eicosapentaenoic acid), R3 (0,163 mg 5,8,11,14 eicosatetraenoic acid), R4 (0,326 mg 5,8,11,14 eicosatetraenoic acid), R5 (20 mg cholesterol NF), R6 (40 mg cholesterol NF). Cholesterol and fatty acid treatment were given orally for five days in succession for each treatment group. Data were analyzed with one-way analyze, and then continued with orthogonal contrast test and morphometric test. The research output, omega 3 , omega 6 fatty acid with double dose $(0,326 \mathrm{mg})$, showed the best response: the increase of the testis weight, height, diameter, and volume. The highest hormone testosterone level was showed by R2 treatment. The conclusion is that using $0,326 \mathrm{mg}$ omega 3 and omega 6 fatty acid affected the reproduction organ's improvement and male quail's blood plasma and hormone testosterone level.
\end{abstract}

Keywords: Omega 3, Omega 6, Cholesterol, Male Reproduction

\section{PENDAHULUAN}

Burung puyuh merupakan salah satu ternak unggas yang berpotensi untuk dikembangkan. Ada beberapa usaha yang dapat dilakukan untuk mempertahankan dan meningkatkan populasi burung puyuh, salah satunya adalah melalui peningkatan produktivitas pejantan. Kualitas pejantan antara lain dapat dideteksi melalui kualitas suara kicauannya, karena kicauan yang merdu berhubungan dengan kadar hormon testosteron ternaknya dan sangat mempengaruhi birahi hewan betina pasangannya.

Kicauan burung jantan yang merdu, adalah tanda bahwa burung tersebut telah dewasa kelamin dan menunjukkan kekuasaannya. Hormon yang berperan dalam perkembangan seksual seekor burung puyuh jantan adalah hormon steroid, diantaranya testosteron yang berfungsi dalam proses spermatogenesis, perkembangan alat reproduksi luar dan tanda-tanda kelamin sekunder seperti suara (Hardjosubroto dan Astuti, 1993 ; Nalbandov, 1990 ), serta sebagai komponen dalam pembentukan kolesterol (Harper et al., 1977; Tranggono, 2001). 
Kolesterol merupakan prekursor dalam biosintesis androgen, termasuk testosteron (Muryanti, 2005). Kolesterol terdapat bebas dalam gabungan ester dengan asam lemak tidak jenuh yang bermolekul tinggi. Asam lemak tidak jenuh merupakan asam lemak essensial yang merupakan asam lemak omega yang tinggi seperti omega 3, omega 6 dan omega 9.

Mengingat manfaat dari bahan pakan sumber asam lemak essensial tersebut di atas, maka perlu dilakukan penelitian ini dengan tujuan untuk mengetahui pengaruh penggunaan asam lemak omega 3, omega 6 dan kolesterol dalam pakan terhadap peningkatan kadar hormon testosteron dan penampilan reproduksi puyuh jantan (coturnix coturnix japonica), diantaranya pada peningkatan kualitas suara dan ukuran testis yang merupakan tolak ukur dari peningkatan kadar hormon reproduksi/hormon testosteron untuk tujuan pembibitan ternak burung puyuh. Berdasarkan hal tersebut diharapkan mendapatkan bibit burung puyuh unggul dengan kualitas reproduksi yang tinggi berdasarkan kualitas suara, ukuran testis dan kadar hormon testosteron plasma darah.

\section{METODE PENELITIAN}

Penelitian ini menggunakan 175 ekor burung puyuh jantan (Coturnix coturnix japonica), berumur enam (6) minggu dengan berat badan berkisar antara $95 \mathrm{~g}$ - $125 \mathrm{~g}$. Puyuh jantan sebanyak 175 ekor dibagi secara acak menjadi tujuh (7) kelompok perlakuan prekursor hormon testosteron. Adapun perlakuan yang dilakukan yaitu ; R-0 (Pakan kontrol), R-1 (0,163 mg omega 3/100 g BB puyuh/ekor/hari), R-2 (0,326 mg omega 3/100 g BB puyuh/ekor/hari), R-3 (0,163 mg omega 6/100 g BB puyuh/ekor/hari), R-4 (0,326 mg omega 6/100 g BB puyuh/ekor/hari), R-5 (20 mg kolesterol/100 g BB puyuh/ekor/hari) dan R-6 (40 mg kolesterol /100 g BB puyuh/ekor/hari) yang direkomendasikan WHO (World Health Organization). Bahan pakan yang digunakan untuk menyusun ransum penelitian terdiri dari jagung kuning, tepung ikan, bekatul, bungkil kedelai, meat bone meal, premix dengan kadar protein kasar sekitar 20,5\% dan energi termetabolis $2600 \mathrm{kcal} / \mathrm{kg}$.

Susunan pakan perlakuan seperti pada Tabel 1. Pakan perlakuan disusun berdasarkan hasil perhitungan dari Tabel komposisi bahan pakan menurut NRC (1994). Pemberian pakan dilakukan pada pagi pukul $06: 00$ dan sore pukul 16:00 WIB dengan kebutuhan masing-masing puyuh sebanyak 20 $\mathrm{g} /$ hari/ $100 \mathrm{~g}$ BB. Air minum diberikan secara ad libitum.

Tiga (3) macam sumber prekursor hormon testosteron yang digunakan adalah asam lemak omega3 sintetis (eicosapentaenoic acid), omega-6 sintetis (5,8,11,14 eicosatetraenoic acid) dan kolesterol sintetis (cholesterol NF). Perlakuan asam lemak dan kolesterol diberikan per oral dengan spet injeksi yang ujungnya diganti dengan kanul, selama lima (5) hari dan diberikan satu kali setiap hari dengan waktu pemberian yang sama untuk masing-masing kelompok perlakuan.

Tabel 1. Komposisi kimia bahan pakan penelitian.

\begin{tabular}{lccccccc}
\hline Bahan Pakan & $\begin{array}{c}\text { Komposisi } \\
(\mathbf{\%})\end{array}$ & $\begin{array}{c}\text { PK } \\
\mathbf{( \% )}\end{array}$ & $\begin{array}{c}\text { LK } \\
(\mathbf{\%})\end{array}$ & $\begin{array}{c}\text { SK } \\
(\mathbf{\%})\end{array}$ & $\begin{array}{c}\text { Ca } \\
(\mathbf{\%})\end{array}$ & $\begin{array}{c}\text { P } \\
(\mathbf{\%})\end{array}$ & $\begin{array}{c}\text { EM } \\
(\mathbf{K c a l} / \mathbf{k g})\end{array}$ \\
\hline Jagung kuning & 56 & 5,64 & 2,05 & 1,18 & 0,11 & 0,07 & 1622,02 \\
Bekatul & 13 & 1,65 & 1,54 & 1,52 & 0,11 & 0,2 & 304,50 \\
Bungkil kedelai & 18 & 9,57 & 0,26 & 1,52 & 0,17 & 0,19 & 494,63 \\
Meat bone meal & 5,5 & 3,65 & 0,61 & 0,16 & 0,61 & 0,31 & 180,86 \\
CaC03 & 6 & - & - & - & 0,54 & - & - \\
DL-metionin & 0,30 & - & - & - & - & - & - \\
L-Lysin & 0,35 & - & - & - & - & - & - \\
NaCl & 0,22 & - & - & - & - & - & - \\
Premix & 0,65 & - & - & - & - & - & - \\
\hline Jumlah & $\mathbf{1 0 0 , 0 0}$ & $\mathbf{2 0 , 5 1}$ & $\mathbf{4 , 4 6}$ & $\mathbf{4 , 3 8}$ & $\mathbf{1 , 5 4}$ & $\mathbf{0 , 7 7}$ & $\mathbf{2 6 0 2 , 0 1}$ \\
\hline
\end{tabular}

Keterangan :

$\mathrm{EM}=$ Energi Metabolisme 


\section{Pengambilan dan Pengumpulan Data}

Tahap penelitian terdiri dari kegiatan pemberian pakan selama 20 minggu, Pengukuran panjang, lingkar dan berat testis puyuh jantan serta pembuatan preparat mikroanatomi testis menggunakan metode HE (Hematoxilin-Eosin), dilakukan di Laboratorium Patologi Fakultas Biologi UGM; sedangkan pengukuran kadar hormon testosteron dianalisis dengan teknik RIA (Radio Immuno Assay) di Laboratorium Pramita Yogyakarta ; pengukuran kadar kolesterol, High Density Lipoprotein (HDL) dan Low Density Lipoprotein (LDL) di analisis dengan metode CHODP-PAP di Laboratorium Penelitian dan Pengujian Terpadu (LPPT) UGM.

Hasil pengamatan pada ukuran testis (panjang, lingkar dan berat testis), preparat mikroanatomi testis, kadar hormon testosteron, kadar kolesterol, HDL serta LDL dianalisis secara kualitatif dengan cara membandingkan hasil pengamatan antar perlakuan dan kontrol.

\section{Ukuran Testis dan Profil Histologi Testis Burung Puyuh}

Pengukuran panjang, lingkar dan berat testis puyuh jantan : Berat testis diukur dengan menimbang testis kiri dan kanan. Volume testis di ukur dengan memasukkan testis ke dalam gelas ukur berisi $\mathrm{NaCl}$ fisiologis, peningkatan volume yang terjadi diasumsikan sebagai volume testis. Panjang dan lingkar diukur menggunakan pita meter. Sedangkan pmbuatan preparat mikroanatomi testis burung puyuh, menggunakan metode HE (Hematoxilin-Eosin), kemudian diamati di bawah mikroskop.

\section{Kadar Hormon Testosteron, Kolesterol, HDL dan LDL}

Darah diambil dengan spuit $3 \mathrm{ml}$ dari jantung dan ditempatkan pada tabung ependrof dibiarkan semalam, kemudian disentrifuge $5000 \mathrm{rpm}$ selama 10 menit, cairan bening merupakan serum darah, kemudian dianalisis dengan metode ELFA (Enzyme-Linked Flourescence Immunoassay) menggunakan KIT VIDAS testosteron untuk mengetahui kadar hormon testosteron, sedangkan untuk pengukuran kadar kolesterol, High Density Lipoprotein (HDL) dan Low Density Lipoprotein (LDL) menggunakan metode CHODP-PAP.

\section{HASIL DAN PEMBAHASAN}

\section{Perbandingan dan ukuran testis puyuh jantan}

Data hasil pengukuran testis disajikan pada Tabel 2, kondisi histologis secara mikroskopis terlihat pada gambar 1. Untuk mengetahui perbedaan organ reproduksi testis burung puyuh jantan (Coturnix coturnix japonica), maka setelah akhir penelitian tiga (3) ekor pejantan dari masing-masing perlakuan dipotong, diambil testisnya, diukur dan ditimbang, serta dilakukan pembuatan preparat histologis testis.

Tabel 2. terlihat bahwa burung puyuh yang diberi perlakuan R-2, menunjukkan total berat, ratarata panjang, rata-rata lingkar dan total volume testis yang lebih tinggi dibandingkan perlakuan lain, seperti yang tertera pada Tabel 2

Tabel 2. Rerata ukuran testis burung puyuh jantan

\begin{tabular}{|c|c|c|c|c|c|c|c|c|c|c|c|c|}
\hline \multirow{2}{*}{$\begin{array}{l}\text { Perla } \\
\text { kuan }\end{array}$} & \multicolumn{3}{|c|}{ Berat (g) } & \multicolumn{3}{|c|}{ Panjang $(\mathrm{cm})$} & \multicolumn{3}{|c|}{ Lingkar (cm) } & \multicolumn{3}{|c|}{ Volume (ml) } \\
\hline & Total & $\mathrm{Ka}$ & $\mathrm{Ki}$ & Rerata & $\mathrm{Ka}$ & $\mathrm{Ki}$ & Rerata & $\mathrm{Ka}$ & $\mathrm{Ki}$ & Total & $\mathrm{Ka}$ & $\mathrm{Ki}$ \\
\hline R0 & 2,84 & 1,42 & 1,42 & 1,75 & 1,60 & 1,90 & 3,95 & 3,80 & 4,10 & 2,00 & 1,00 & 1,00 \\
\hline R1 & 2,68 & 1,72 & 0,96 & 1,60 & 1,60 & 1,60 & 3,70 & 3,80 & 3,60 & 1,90 & 1,00 & 0,90 \\
\hline R2 & 5,27 & 2,34 & 2,93 & 2,00 & 1,90 & 2,10 & 4,70 & 5,00 & 4,40 & 4,00 & 2,00 & 2,00 \\
\hline R3 & 2,87 & 1,40 & 1,47 & 1,95 & 1,80 & 2,10 & 3,65 & 70 & 3,60 & 1,90 & 00 & 0,90 \\
\hline R4 & 3,23 & 1,49 & 1,74 & 2,00 & 1,80 & 2,20 & 3,75 & 3,90 & 3,60 & 3,00 & 1,50 & 1,50 \\
\hline R5 & 3,32 & 1,70 & 1,62 & 1.95 & 1,80 & 2,10 & 3,87 & 4,00 & 3,75 & 3,00 & 2,00 & 1,00 \\
\hline R6 & 3,00 & 1,45 & 1,55 & 1.70 & 1,60 & 1,80 & 3,85 & 4,50 & 3,20 & 2,80 & 1,30 & 1,50 \\
\hline
\end{tabular}

Keterangan : $\mathrm{Ka}=$ Kanan $; \mathrm{Ki}=$ Kiri 
Dalam Tabel 2. terlihat bahwa testis sebelah kanan dan kiri burung puyuh yang diberi perlakuan asam lemak atau kolesterol mempunyai ukuran yang lebih serasi. Hal ini sesuai dengan pendapat Surai et al. (2000) yang menyatakan bahwa penambahan arachionat $(20: 4 n-6)$ pada ayam ternyata meningkatkan kandungan asam-asam lemak pada testis terutama DHA (22:4n-6) dan EPA (20:5n-3), meningkatkan berat testis serta menyebabkan peningkatan massa testis dan meningkatkan jumlah sperma. Peningkatan bobot testis tersebut dikarenakan terjadinya peningkatan proses spermatogenesis (Catchpole and Slater, 1995). Hasil penelitian ini yang menunjukkan bahwa bobot testis tertinggi adalah disebabka.n oleh perlakuan asam lemak dan kolesterol, akan didukung dengan terjadinya peningkatan kadar hormon testosteron, seperti yang tertera pada Tabel 3 .

Hasil penelitian terhadap profil histologi testis terlihat pada Gambar 1

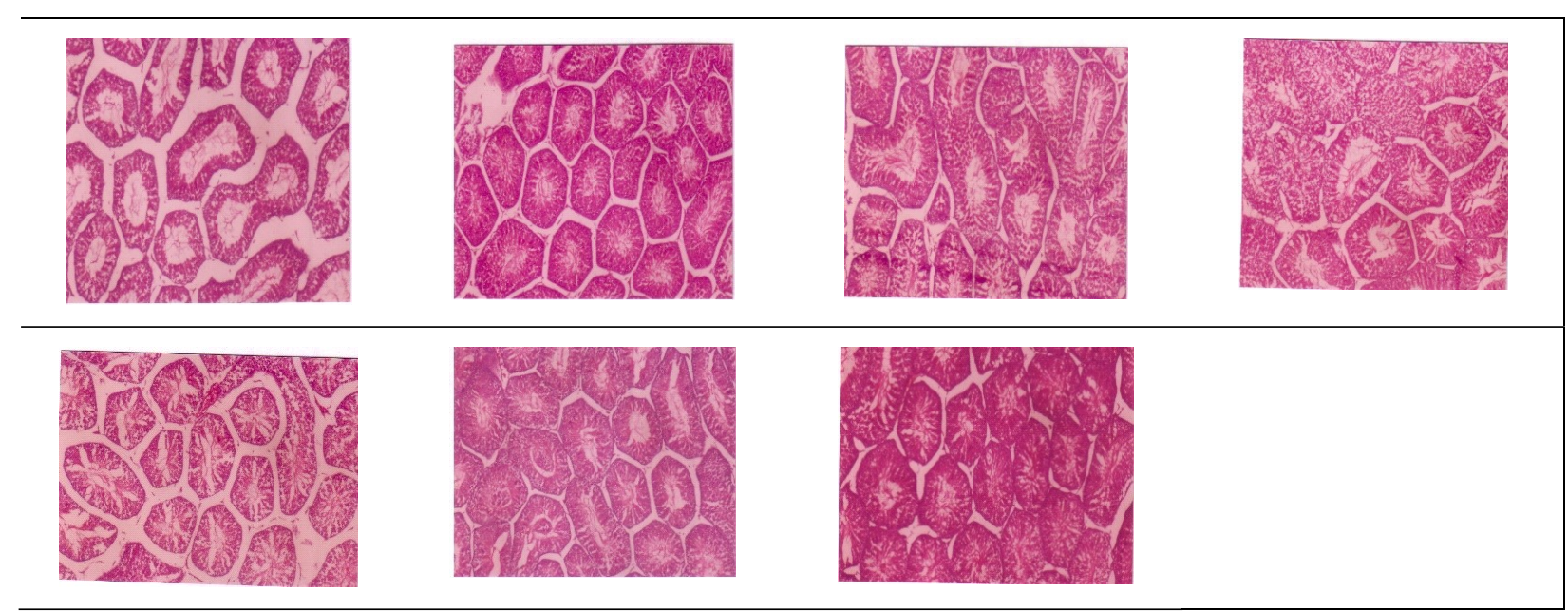

Gambar 1. Potongan melintang Tubulus seminiferus profil histologi testis burung puyuh umur 12 minggu pada pembesaran $400 \mathrm{x}$

Secara histologis tampak terjadinya perbedaan morfologis testis burung puyuh antara kelompok perlakuan (R-1 sampai R-6) dengan kontrol (R-0). Testis puyuh yang diberi perlakuan asam lemak omega dan kolesterol mempunyai tubulus seminiferus yang lebih rapat dengan spermatogenesis yang lengkap dibandingkan dengan testis puyuh tanpa perlakuan. Hal ini di duga karena pemberian asam lemak omega dan kolesterol dapat meningkatkan dan menambah lebar diameter dari tubulus seminiferus dengan keadaan sel spermatogenik yang normal. Tubulus seminiferus pada perlakuan R0 hanya berisi sejumlah sel-sel spermatogenik (seperti terlihat pada Gambar 1., jarak antara masing-masing tubulus seminiferus cukup renggang). Sedikitnya sel-sel spermatogenik di duga karena kurangnya kadar ICSH untuk proses spermatogenesis yang normal sehingga deferensiasi sel germinal terganggu, karena ICSH menstimulir pertumbuhan sel-sel interstitial terutama sel Leydig (Salisbury dan VanDemark, 1985 ; Yuwanta, 1993).

Pada Gambar 1. terlihat bahwa tubulus seminiferus dari testis burung puyuh yang paling rapat dengan diameter yang paling lebar serta keadaan sel spermatogenik normal, ditunjukkan oleh perlakuan R-2. Perlakuan R-1, R-3, R-5 dan R-6 juga menunjukkan tubulus seminiferus testis yang kompak dan serasi dengan kondisi sel spermatogenik yang normal. Hal ini sesuai dengan pendapat Rettersol et al. (1998) yang menyatakan bahwa asam lemak tidak jenuh ganda terutama (20:4n-6), (22:4n-6) dan (20:5n3) akan merangsang perkembangan spermatogenesis, sehingga akan menyebabkan peningkatan massa testis dan terjadinya perkembangan spermatozoa dalam jumlah besar di dalam jaringan.

\section{Kadar hormon testosteron burung puyuh jantan}

Hasil uji kadar hormon testosteron, kolesterol, HDL dan LDL burung puyuh jantan setelah diberi perlakuan omega-3, omega-6 atau kolesterol murni, menunjukkan hasil yang beragam (Tabel 3). Semakin tinggi dosis pemberian omega-3 dan omega-6, maka semakin meningkat kadar hormon testosteron yang dihasilkan, tetapi sebaliknya, semakin tinggi dosis kolesterol yang diberikan maka 
semakin menurun kadar hormon testosteron yang dihasilkan. Hal ini terjadi kemungkinan karena dosis asam lemak omega (omega-3 dan omega-6) yang seharusnya diberikan pada ternak unggas khususnya burung puyuh adalah $0,326 \mathrm{mg} / 100 \mathrm{~g}$ BB puyuh/ekor/hari, yaitu lebih tinggi dari rekomendasi WHO untuk diberikan pada ternak besar (mamalia) maupun pada manusia. Sementara untuk pemberian kolesterol, adalah sebaliknya.

Tabel 3. Rerata kadar hormon testosteron, kolesterol, HDL dan LDL burung puyuh jantan.

\begin{tabular}{clcccc}
\hline No & \multicolumn{1}{c}{ Dosis (mg/100 g bb/hari) } & $\begin{array}{c}\text { Kadar } \\
\text { Testosteron } \\
(\mathrm{ng} / \mathrm{ml})\end{array}$ & $\begin{array}{c}\text { Kadar } \\
\text { kolesterol } \\
(\mathrm{mg} / \mathrm{dl})\end{array}$ & $\begin{array}{c}\text { Kadar } \\
\text { HDL }\end{array}$ & $\begin{array}{c}\text { Kadar } \\
\text { LDL }\end{array}$ \\
$(\mathrm{mg} / \mathrm{dl})$
\end{tabular}

Meningkatnya kadar hormon testosteron pada perlakuan omega-3 dosis tinggi yang ditunjukkan pada Tabel 3, diimbangi oleh menurunnya kadar kolesterol total (174.1 mg / dl ), HDL (46.3 mg / dl) dan LDL (18, $04 \mathrm{mg} / \mathrm{dl}$ ) pada serum darah burung puyuh jantan, terjadi karena sebagian kolesterol telah disintesis menjadi hormon testosteron. Rettersol et. Al., (1998), menyatakan bahwa hormon testosteron disintesis dari kolesterol dalam sel Leydig dan kelenjar adrenal, sehingga secara otomatis akan mempengaruhi juga kandungan HDL dan LDL di dalam serum darah. Akibatnya, pada saat di analisis kadar kolesterol, LDL dan HDL yang terdeteksi menjadi turun/sedikit. Meningkatnya kadar hormon testosterone pada perlakuan omega-3 dan omega- 6 dosis tinggi disebabkan oleh meningkatnya aktivitas sel-sel Leydig yang mensintesis hormon testosterone, yang diduga karena tingginya kandungan HDL (lipoprotein berkepadatan tinggi) yang banyak terdapat di dalam asam lemak tidak jenuh, diantaranya asam lemak omega yang banyak mengandung EPA (omega-3) dan arakhidonat (omega-6).

Dari hasil penelitian ini dapat diketahui bahwa asam lemak omega-3 dan omega-6 dosis 0,326 $\mathrm{mg} / \mathrm{hari} / 100 \mathrm{~g} \mathrm{bb}$, dapat meningkatkan kadar testosteron dalam plasma darah ; tetapi sebaliknya, dosis yang direkomendasikan oleh WHO $(0,163 \mathrm{mg})$, menunjukkan nilai yang lebih rendah dari kontrol. Pemberian kolesterol dengan dosis $20 \mathrm{mg} / \mathrm{hari} / 100 \mathrm{~g}$ bb menunjukkan kadar kolesterol yang lebih tinggi dalam plasma darah burung puyuh jantan di banding pemberian kolesterol dengan dosis $40 \mathrm{mg} / \mathrm{hari} / 100$ g bb. Pemberian kolesterol sesuai dosis WHO $(20 \mathrm{mg})$ maupun dosis tinggi $(40 \mathrm{mg})$ menunjukkan kadar testosteron lebih tinggi dibandingkan kontrol.

\section{KESIMPULAN}

Penggunaan asam lemak omega 3 atau omega 6 dosis tinggi $(0,326 \mathrm{mg} / 100 \mathrm{~g}$ BB ternak/hari) dapat meningkatkan kadar hormon testosteron dan ukuran testis baik pada berat, panjang, lingkar dan volume testis pada burung puyuh jantan. Hal ini berpengaruh terhadap peningkatan reproduksi burung puyuh dan peningkatan pendapatan peternak burung puyuh.

\section{DAFTAR PUSTAKA}

Catchpole and Slater., 1995. Bird Songs : Biological Themes and Variations. Cambridge University Press.

Harper, H.A., V.W. Rodwel and P.A. Mayes. 1977. Biokimia. Edisi 17. tercemahan oleh M. Muliawan. Universitas Inonesia, Jakarta. 
Muryanti, Y. 2005. Kadar Testosteron Serum Darah dan Kualitas Spermatozoa Mencit (Mus musculus L.) setelah diberi Ekstrak Biji Saga (Abrus precatorius L.), Tesis Fakultas Pascasarjana, Yogyakarta.

Nalbandov. A.V. 1990. Fisiologi Reproduksi pada Mamalia dan Unggas. Alih Bahasa : Sunaryo Keman. Jakarta. Penerbit Universitas Indonesia.

NRC. 1994. Nutrien Requirement of Poultry. The 9th Ed., Washington D. C. USA. National Academic Press.

Rettersol, K.T., B. Hugen, B. Woldseth and B.O. Christopherson. 1998. A comparative study of the metabolism of n-9, n-6 and n-3 fatty acids in testicular cells from immature rat. Biochim. Biophys. Acta. 1392 : 59-72.

Salisbury, G. W. dan N. L. VanDemark. 1985. Fisiologi Reproduksi dan Inseminasi Buatan pada Sapi. Terjemahan R. Djanuar. Yogyakarta. Gadjah Mada University Press.

Surai, P.F., R.C. Noble, N.H.C. Sparks and B.K. Speake. 2000. Effect of Long-term Supplementation With Arachidonic or Docosahexaenoic Acids on Sperm Production in The Broiler Chicken. Journal of Reproduction and Fertility. $120: 257-264$.

Tranggono. 2001. Lipid dalam Perspektif Ilmu dan Teknologi Pangan. Pidato Pengukuhan Guru Besar Fak. Teknologi Pertanian UGM.

Tri Yuwanta. 1993. Perencanaan dan Tata Laksana Pembibitan Unggas Sub Bagian Inseminasi Buatan Pada Unggas. Program Studi Ilmu Ternak. Fakultas Pascasarjana Universitas Gadjah Mada, Yogyakarta. 